\title{
Thermostability of Cell Membranes as a Measure of Heat Tolerance and Relationship to Flowering Delay in Chrysanthemum
}

\author{
D.M. Yeh' and H.F. Lin \\ Department of Horticulture, National Taiwan University, Taipei, Taiwan, ROC
}

AdDitional INDEX words. Dendranthema $\times$ grandifolia, electrolyte leakage, flowering

\begin{abstract}
Identification of heat-tolerant chrysanthemum [Dendranthema xgrandifolia (Ramat.) Kitamura] genotypes for commercial production in hot areas of the world is desirable. The extent to which electrolyte leakage from chrysanthemum leaf discs, measured using a test for cell membrane thermostability (CMT), could be related to the delay in flowering induced by heat in the field-grown plants was determined. The relationship between the relative injury (RI) occurring in leaf tissue discs of chrysanthemum cultivars and treatment temperature was sigmoidal. A single temperature treatment at $50{ }^{\circ} \mathrm{C}$ resulted in injury values near the midpoint of the sigmoidal response curve and showed the greatest sensitivity in detecting genotypic differences in heat tolerance. The cultivars with a low RI value are those with the greater CMT and shorter heat-induced delay to flowering.
\end{abstract}

High temperatures during the growing season can have considerable detrimental effects on plant growth and yield (Hall, 1992). Techniques for rapid and easy identification of heattolerant genotypes during breeding programs for sub-tropical and tropical areas are desirable. Cell membrane thermostability (CMT), measured as electrolyte leakage from leaf discs over a range of temperatures, is a sensitive and rapid method to evaluate heat tolerance in plants (Sullivan, 1972; Wu and Wallner, 1993). Several studies have shown the effectiveness of CMT testing in detecting genetic variability for heat tolerance among several agronomic, fruit, and vegetable crops (Chen et al., 1982; Ingram and Buchanan, 1984; Lester, 1985; Martineau et al., 1979; Saadalla et al., 1990; Sullivan and Ross, 1979). Leaf CMT was highly correlated with fruit set and yield under high temperature conditions (Fokar et al., 1998; Martineau et al., 1979; Sullivan and Ross, 1979). However, little information is available on using CMT to indicate heat tolerance of floricultural crops.

In chrysanthemum (Dendranthema $\times$ grandifolia), the phenomenon of a heat delay in time to flowering (anthesis) is induced by temperatures of 26 to $32^{\circ} \mathrm{C}$ (Cathey, 1954; Cockshull, 1979; Karlsson et al., 1989; Whealy et al., 1987). For chrysanthemums grown during the summer, in greenhouses, or under tropical field conditions, high temperature limits production. Breeding heat-tolerant or heat-delay insensitive genotypes is vital (Anderson and Ascher, 2001). Shibata and Kawata (1987) measured differences in the degree of heat delay among Japanese chrysanthemum cultivars directly by growing the plants to flowering during summer and found that some genotypes may be useful for introducing heat tolerance. Screening for heat tolerance using field evaluation techniques is slow and frequently heat stress conditions during flowering are inconsistent (De Jong, 1989). Because thermotolerance at the seedling and flowering stages is generally well-correlated in other species, for example in wheat (Triticum aestivum L.) (Fokar et al., 1998; Saadalla et al., 1990) and cowpea [Vigna unguiculata (L.) Walp.] (Ismail and Hall, 1999), preliminary field screening with chrysanthemum could also be successful if carried out with young vegetative plants.

Received for publication 17 Dec. 2002. Accepted for publication 19 May 2003. This paper is a portion of a thesis submitted by H.F. Lin. Use of trade names does not imply endorsement of products named or criticism of similar products not mentioned.

${ }^{1}$ Corresponding author; e-mail dmyeh@ntu.edu.tw.
The present study examined heat tolerance in leaves taken from a wide range of young chrysanthemum cultivars, using leaf electrolyte leakage as a measure of CMT and then testing how well this related to the heat-induced delay in flowering of plants grown in the field under natural high temperatures.

\section{Materials and Methods}

Stock Plants. Rooted chrysanthemum cuttings of the cultivars (Table 1) were planted in 21-cm-diameter plastic pots each containing sphagnum peat (Fafard No. 1, Conrad Fafard Inc., Agawam, Mass.), perlite and vermiculite mixed in equal volumes. After planting, the cuttings were grown in a greenhouse at a mean daily temperature of $27^{\circ} \mathrm{C}$ under 11.5 to $12 \mathrm{~h}$ natural daylength augmented, to maintain vegetative growth, by a night break from 2200 to 0200 HR using incandescent lamps giving $2.2 \mu \mathrm{mol} \cdot \mathrm{m}^{-2} \cdot \mathrm{s}^{-1}$ (PAR, 400 to $700 \mathrm{~nm}$ ) at plant level. The plants were fertilized weekly with water-soluble $20.0 \mathrm{~N}-4.4 \mathrm{P}-24.9 \mathrm{~K}$ (The Scotts Co., Marysville, Ohio) at 300 ppm N. Tips of the shoots were pinched off above the sixth leaf after plants were established to encourage lateral growth.

Cell membrane thermostability. On 5 Nov. 2001, cuttings ( 6 to $8 \mathrm{~cm}$ long) of seven chrysanthemum cultivars (Fig. 1) were obtained from stock plants and were evaluated for CMT following procedures described by Martineau et al. (1979) with minor modifications. CMT was measured at 25, 30, 35, 40, 45, 50, 55, 60,65 , and $70^{\circ} \mathrm{C}$.

A sample for assay consisted of a paired set $\left(25^{\circ} \mathrm{C}\right.$ control and another treatment) of five 9-mm-diameter leaf disc samples (53.7 $\pm 0.9 \mathrm{mg}$ fresh weight) cut from a group of five recently fully expanded leaves with a cork borer. Prior to assay, the paired set of leaf discs was placed into two separate 75-mL test tubes and rinsed thoroughly with three rapid changes of distilled water.

Leaf discs were then placed in $25 \times 150$-mm test tubes containing $1 \mathrm{~mL}$ distilled water to prevent secondary water stress. Three tubes per treatment were placed in a heated, circulating water bath for $30 \mathrm{~min}$ at each temperature, while the control tubes were maintained at $25{ }^{\circ} \mathrm{C}$ for the same period. Distilled water $(15 \mathrm{~mL})$ was added to each tube following elevated temperature exposure. Samples were placed on an orbital shaker for $24 \mathrm{~h}$ at $10 \pm 3{ }^{\circ} \mathrm{C}$, and then solution conductivity was measured with 
Table 1. Relative injury (RI) as determined by the cell membrane thermostability test at 25 and $50{ }^{\circ} \mathrm{C}$ for 30 min for 21 cultivars of chrysanthemum.

\begin{tabular}{|c|c|c|c|}
\hline \multirow[b]{2}{*}{ Cultivar } & \multicolumn{3}{|c|}{ Relative injury (\%) } \\
\hline & $25^{\circ} \mathrm{C}^{\mathrm{z}}$ & $50{ }^{\circ} \mathrm{C}^{\mathrm{z}}$ & Calibratedy \\
\hline Yellow Windmill & $13.1 \mathrm{~cd}$ & $43.2 \mathrm{fg}$ & $34.6 \mathrm{fg}$ \\
\hline Fen-Yen & $13.2 \mathrm{~cd}$ & $52.3 \mathrm{efg}$ & $45.3 \mathrm{efg}$ \\
\hline Huang Tung-Chien & $12.9 \mathrm{~cd}$ & $57.0 \mathrm{def}$ & $50.6 \mathrm{def}$ \\
\hline Hsin Chung-Huang & $12.0 \mathrm{~d}$ & $62.1 \mathrm{cde}$ & $56.8 \mathrm{cde}$ \\
\hline Huang Ching-Chin & $15.2 \mathrm{bc}$ & 65.7 bcde & 59.6 bcde \\
\hline Hua Chao Feng & $13.1 \mathrm{~cd}$ & 66.4 bcde & 61.2 bcde \\
\hline Chun Chih-Wan & $13.1 \mathrm{~cd}$ & 66.5 bcde & 61.4 bcde \\
\hline Pai Tung-Yang & $13.4 \mathrm{~cd}$ & 66.9 bcde & 61.7 bcde \\
\hline Pai Ting-Er & $13.8 \mathrm{~cd}$ & 67.1 bcde & $61.8 \mathrm{bcde}$ \\
\hline Shih Wan-Hung & $14.3 \mathrm{bcd}$ & $75.9 \mathrm{abc}$ & $71.9 \mathrm{abc}$ \\
\hline Chu-Feng & $12.5 \mathrm{~cd}$ & $77.2 \mathrm{abc}$ & $73.8 \mathrm{abc}$ \\
\hline Daymark & $14.9 \mathrm{bcd}$ & $78.7 \mathrm{ab}$ & $75.0 \mathrm{ab}$ \\
\hline Yen Chih-Hung & $14.0 \mathrm{~cd}$ & $83.6 \mathrm{a}$ & $81.0 \mathrm{a}$ \\
\hline
\end{tabular}

${ }^{2}$ Calculated as (initial conductivity/final conductivity) $\times 100$.

yCalibrated $\mathrm{RI}=\{1-[1-(\mathrm{T} 1 / \mathrm{T} 2)] /[1-(\mathrm{C} 1 / \mathrm{C} 2)]\} \times 100$.

xMean separation within columns by Duncan's multiple range test at $P \leq 0.05$.

a conductivity/TDS meter (model 44600; Hach Co., Loveland, calculated as follows: RI $(\%)=\{1-[1-(\mathrm{T} 1 / \mathrm{T} 2)] /[1-(\mathrm{C} 1 / \mathrm{C} 2)]\}$ Colo.). The tubes then were capped with foil, autoclaved $(121 \times 100$, where $\mathrm{T}$ and $\mathrm{C}$ refer to conductance values for treatment ${ }^{\circ} \mathrm{C}, 1.2 \mathrm{~kg} \cdot \mathrm{cm}^{-2}$ ) for $15 \mathrm{~min}$, cooled to $25^{\circ} \mathrm{C}$, and incubated an and control vials, respectively, and subscripts 1 and 2 refer to additional $24 \mathrm{~h}$ before final conductivity measurements were taken. Relative injury (RI) values at 25 and $50^{\circ} \mathrm{C}$ were calculated as (iniinitial and final conductance readings, respectively.

Twenty-one chrysanthemum cultivars were used to measure tial conductivity/final conductivity) $\times 100$. The calibrated RI was the initial conductivity of electrolytes leaking from leaf discs
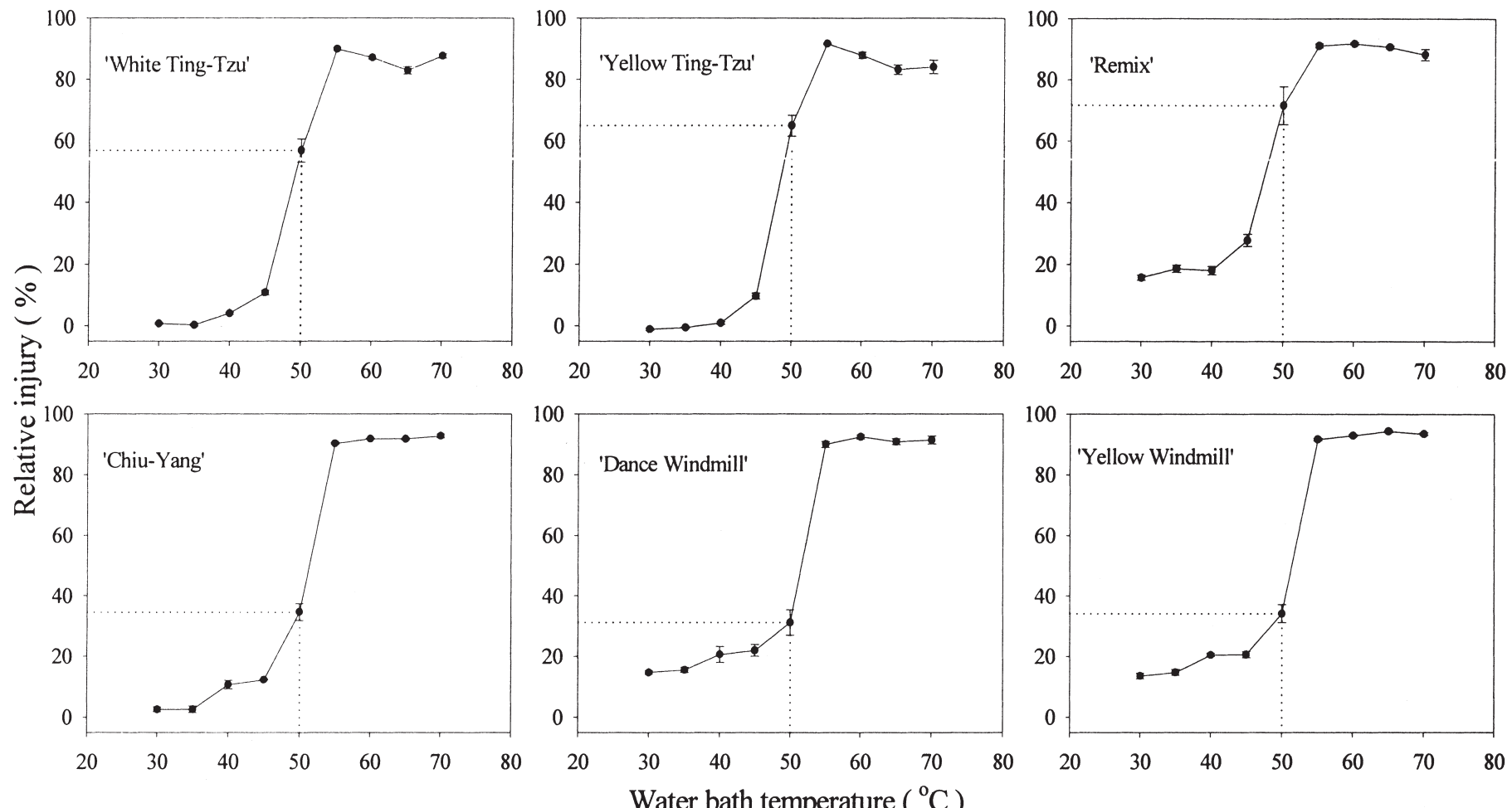

Fig. 1. Effect of water bath temperature on relative injury of chrysanthemum leaf discs. Bars represent standard error of the mean and are not visible if smaller than the symbol. 


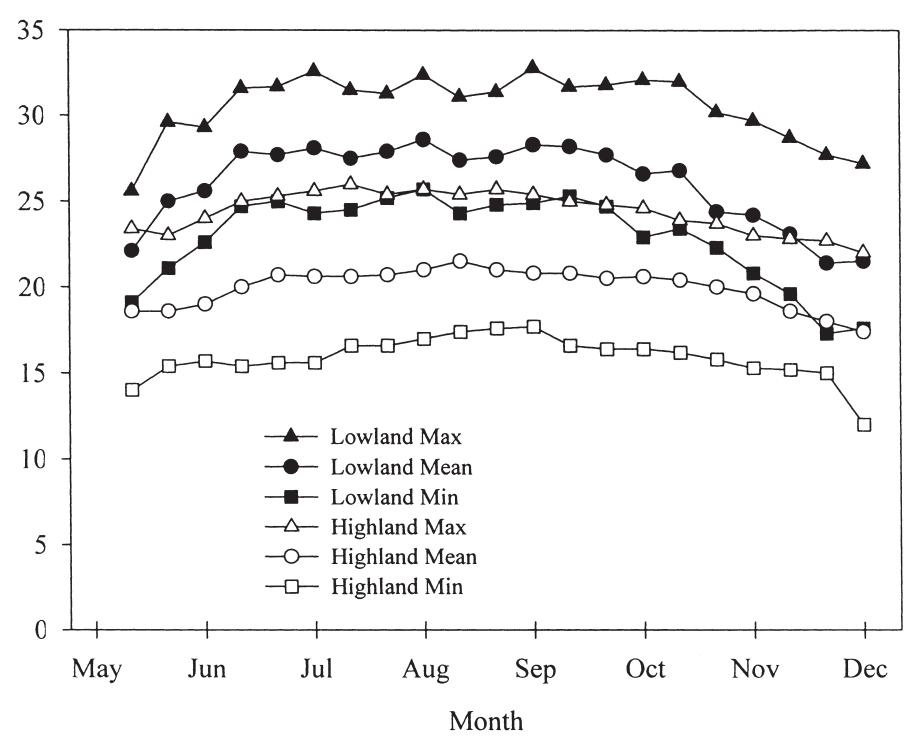

Fig. 2. The maximum, mean and minimum daily temperatures during the experimental period under lowland and highland conditions.

at $25^{\circ} \mathrm{C}$ (control) and $50{ }^{\circ} \mathrm{C}$ for $30 \mathrm{~min}$. Test tubes containing samples were autoclaved at $121^{\circ} \mathrm{C}$ for $15 \mathrm{~min}$ and final solution conductivity was measured again at $25^{\circ} \mathrm{C}$.

Field EVAluation. Rooted cuttings of seven chrysanthemum cultivars were obtained from the stock plants and were planted each month from May to August at Taichung District Agriculture Improvement Station (altitude $50 \mathrm{~m}$, lowland) and at Chun-Yang (altitude $1100 \mathrm{~m}$, highland) under natural field conditions. The thermal environment at the lowland location is typical for commercial chrysanthemum production in Taiwan, where heat stress is frequently considered a limiting factor for summer production.

On each planting date, four plants for each cultivar were set in plots consisting of four rows spaced at $10 \times 12 \mathrm{~cm}$ within and between rows, respectively. Daylengths during the experimental period at each location were similar, ranging from 12 to $14.5 \mathrm{~h}$. Air temperature and radiation were measured at the top of the plant canopy and logged every $30 \mathrm{~min}$ using screened thermocouples and pyranometer sensors (LI-200SZ, LI-COR, Lincoln, Nebr.) attached to a datalogger (LI-200SZ, LI-COR). The daily cumulative radiation received by the plants ranged between 2 and $4 \mathrm{MJ} \cdot \mathrm{m}^{-2} \cdot \mathrm{d}^{-1}$. Days from planting to flowering (first row of disc florets fully open in the terminal inflorescence) was recorded for each plant. Each plant was terminated at flowering or $150 \mathrm{~d}$ after planting if the terminal apex was still vegetative. Costat programming (CoHort Software, Berkeley, Calif.) was used for statistical analysis.

RELATION BETWEen CMT AND HEAT DELAY. The degree of heat delay was calculated following the method of Shibata and Kawata (1987) as the difference between days to flowering in the seven cultivars planted at the lowland site in June and July, and July and August, respectively. Regression analysis was used to determine the relationship between the cultivars' calibrated RI value and their associated degree of heat delay.

\section{Results}

Cell membrane thermostability. The relationship between the RI value of leaf tissue discs of six chrysanthemum cultivars and treatment temperature was sigmoidal (Fig. 1). In the $50{ }^{\circ} \mathrm{C}$ treatment, the RI values were near the center of the inflection points of the response curves and showed the greatest genotypic differences in CMT. For example, the $50{ }^{\circ} \mathrm{C}$ treatment resulted in $65 \%$ and $68 \%$ RI in 'Yellow Ting-Tzu' and 'Remix', but only $32 \%$ and $35 \%$ in 'Chiu-Yang', 'Dance Windmill', and 'Yellow Windmill' respectively. This suggests that differences in heat tolerance of leaf tissues exist between chrysanthemum cultivars which are detectable by CMT.

The RI values of 21 cultivars at $25^{\circ} \mathrm{C}$ differed, but showed a very narrow range (Table 1 ). Genotypic rankings for CMT were similar by both $50{ }^{\circ} \mathrm{C}$ or calibrated $50{ }^{\circ} \mathrm{C}$ calculations, where RI values varied markedly from $32 \%$ to $84 \%$. Clearly, a single heat treatment at $50{ }^{\circ} \mathrm{C}$ can be used to screen large numbers of chrysanthemum cultivars.

Field evaluation. Two locations were chosen to measure the flowering time of chrysanthemums: one in the lowland and one in the highland. Temperatures differed markedly between the two sites as shown in Fig. 2. Temperature increased from May, was consistent between June and October, and then decreased in December when the experiment ended. From June to October, the maximum, mean and minimum temperatures were 32,28 , and $24{ }^{\circ} \mathrm{C}$, respectively, at the lowland, and 25,19 , and $16{ }^{\circ} \mathrm{C}$, respectively, at the highland.

Time from planting to flowering differed among cultivars and planting dates at the highland location (Table 2). The cultivars Huang-Yen, Daymark and Yen Chih-Hung consistently took longer to flowering ( 87 to $95 \mathrm{~d}$ ), compared with other cultivars (63 to 78 d) planted in May or June. Plantings in July or August (mean temperature of $20^{\circ} \mathrm{C}$ ), flowered faster than those in May.

Plants grown at the lowland location were slower to flower than those grown on the highland, even when planted on the same date (Table 3). However, cultivars Fen-Yen and Huang Tung-Chien flowered after the same time period regardless of planting date between May and August when temperatures were high, suggesting that these are heat-delay insensitive chrysanthemums. The cultivars Huang-Yen, Daymark and Yen Chih-Hung on the other hand appeared to be heat-delay sensitive. First, these cultivars

Table 2. Days between planting and flowering of chrysanthemums under highland field conditions.

\begin{tabular}{|c|c|c|c|c|}
\hline \multirow[b]{2}{*}{ Cultivar } & \multicolumn{4}{|c|}{ Planting month } \\
\hline & May & June & July & August \\
\hline Fen-Yen & $74.2 \mathrm{cA}^{\mathrm{z}}$ & $64.3 \mathrm{bAB}$ & $52.8 \mathrm{cB}$ & $50.4 \mathrm{cB}$ \\
\hline Huang Tung-Chien & $60.8 \mathrm{dA}$ & $63.7 \mathrm{bA}$ & $59.5 \mathrm{bA}$ & $50.3 \mathrm{cA}$ \\
\hline Pai Ting-Er & $74.4 \mathrm{cA}$ & $68.4 \mathrm{bA}$ & $64.2 \mathrm{bB}$ & $66.2 \mathrm{bB}$ \\
\hline Huang-Yen & $87.6 \mathrm{abA}$ & $94.2 \mathrm{aA}$ & $78.2 \mathrm{aB}$ & $78.3 \mathrm{aB}$ \\
\hline Daymark & $94.4 \mathrm{aA}$ & $94.7 \mathrm{aA}$ & $78.1 \mathrm{aB}$ & $59.3 \mathrm{bcC}$ \\
\hline
\end{tabular}

zMean separation within columns (lowercase) and rows (uppercase) by Duncan's multiple range test at $P \leq 0.05$. 
Table 3. Days between planting and flowering of chrysanthemums under lowland field conditions.

\begin{tabular}{|c|c|c|c|c|}
\hline \multirow[b]{2}{*}{ Cultivar } & \multicolumn{4}{|c|}{ Planting month } \\
\hline & May & June & July & August \\
\hline Huang Tung-Chien & $80.2 \mathrm{aA}$ & $77.1 \mathrm{dA}$ & $68.3 \mathrm{cA}$ & $72.3 \mathrm{bcA}$ \\
\hline Pai Ting-Er & $84.3 \mathrm{aB}$ & $105.7 \mathrm{bA}$ & $82.6 \mathrm{bB}$ & $79.8 \mathrm{bB}$ \\
\hline Huang-Yen & ---y & $147.2 \mathrm{aA}$ & $124.1 \mathrm{aB}$ & $93.2 \mathrm{aC}$ \\
\hline Daymark & --- & $147.2 \mathrm{aA}$ & $117.4 \mathrm{aB}$ & $79.3 \mathrm{bC}$ \\
\hline
\end{tabular}

zMean separation within columns (lowercase) and rows (uppercase) by Duncan's multiple range test at $P \leq 0.05$.

yDenotes that plants did not flower within $150 \mathrm{~d}$.

remained vegetative for $150 \mathrm{~d}$ after planting in May, when the mean temperature was $28^{\circ} \mathrm{C}$. Second, plants planted in June or July experienced high temperature for a longer time and were delayed in flowering more than those planted in August. Third, these heat sensitive cultivars did not flower until November or December, requiring $\approx 50 \%$ more days to flower than the heat insensitive cultivars planted in June or July.

RELATION BETWEEN CMT AND HEAT DELAY. The heat delay sensitive cultivars had higher RI values (Table 1) and a greater degree of heat delay (Table 3). Regressing the delay in days to flowering versus the associated, calibrated RI values of seven cultivars grown in the lowland showed good linear relationships $(P \leq 0.01)$ for both planting in June and July $\left(R^{2}=0.93\right)$, and July and August $\left(R^{2}=\right.$ 0.74 ), respectively (Fig. 3).

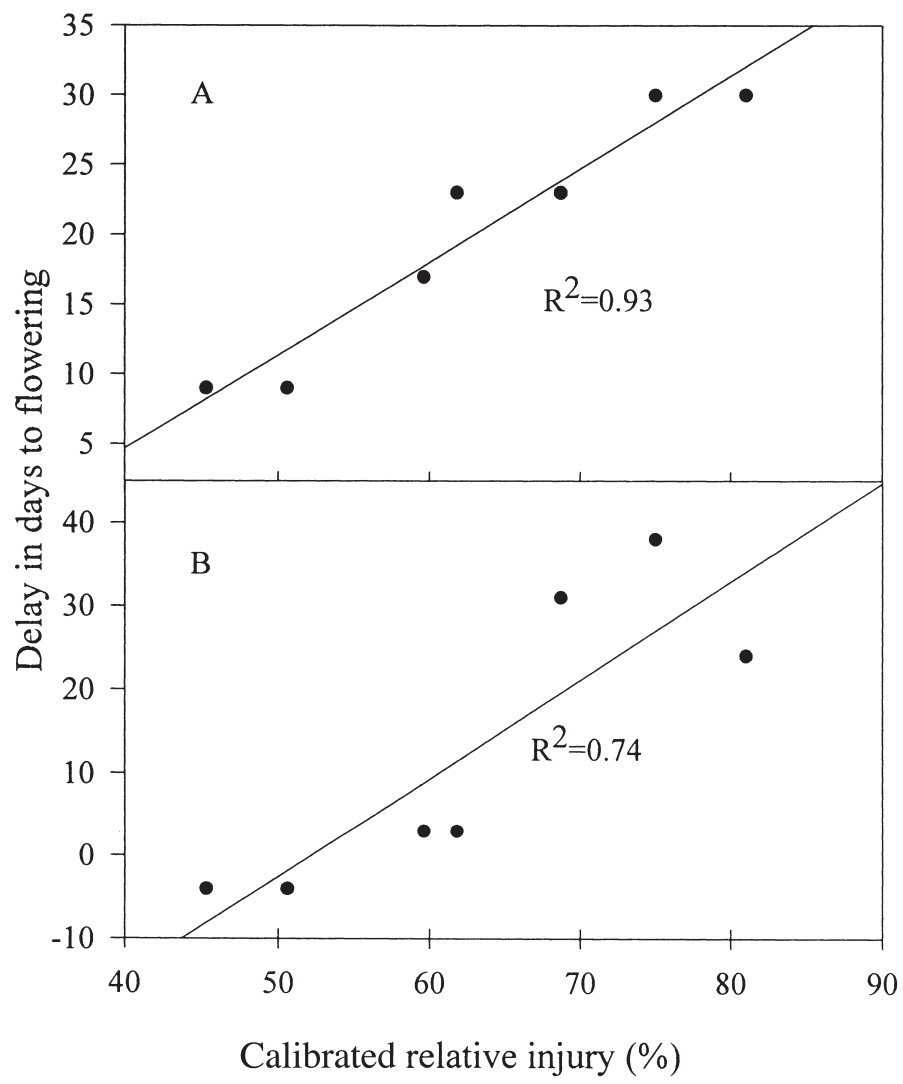

Fig. 3. Relationship between flowering delay and calibrated relative injury of chrysanthemum cultivars grown under lowland conditions. The degree of heat delay was calculated as the difference between days to flowering in plants planted in June and July (A), and July and August (B), respectively.

\section{Discussion}

The electrolyte leakage test is one of the most convenient methods of screening crops for heat tolerance (Lester, 1985; Martineau et al., 1979; Sullivan, 1972). The present study with chrysanthemum showed electrolyte leakage from leaf discs to have a sigmoidal response to increasing temperature (Fig. 1). Similar response curves have been reported for agronomic crops (Chen et al., 1982; Ismail and Hall, 1999; Martineau et al., 1979; Sullivan, 1972), fruit crops (Ahrens and Ingram, 1988; Ingram and Buchanan, 1984), and vegetable crops (Inaba and Crandall, 1988; Lester, 1985).

High temperature tolerance of plants varies with genotype (Ingram and Buchanan, 1984; Lester, 1985) but to derive injury response curves as shown in Fig. 1 for many individual plants would be tedious. From a practical perspective, it is easier to set up a single temperature bath than to set up many at different temperatures. A single temperature treatment at $50{ }^{\circ} \mathrm{C}$ resulted in injury values near the midpoint of the sigmoidal response curve and showed the greatest sensitivity in detecting genotypic differences in heat tolerance (Table 1). A treatment temperature around $50{ }^{\circ} \mathrm{C}$ has been successfully used to screen for heat tolerance in pepper (Capsicum annuиm L.) (Anderson et al., 1990), groundnut (Arachis hypogaea L.) (Chauhan and Senboku, 1996), soybeans [Glycine max (L.) Merr.] (Martineau et al., 1979), and winter wheat (Saadalla et al., 1990). The present study showed that a temperature of $50^{\circ} \mathrm{C}$ can be used to screen chrysanthemum cultivars with confidence. Furthermore, consistent genotypic differences in electrolyte leakage were observed in samples taken from plants grown in the field indicating that the technique is appropriate for screening plants from conventional field breeding programs.

Seven cultivars of chrysanthemum appeared to be day-neutral or quantitative short day plants as they flowered under summer long day conditions on the highland (Table 2). However, three of these cultivars (Huang-Yen, Daymark and Yen Chih-Hung) grown on the lowland site either remained vegetative or were delayed in flowering (Fig. 2, Table 3). Delays in time to anthesis of chrysanthemums by temperatures of 26 to $32{ }^{\circ} \mathrm{C}$ have been reported previously (Cockshull, 1979; Karlsson et al., 1989; Whealy et al., 1987). Two cultivars, Fen-Yen and Huang Tung-Chien, flowered within $80 \mathrm{~d}$ after planting in hot and long day conditions (Fig. 2; Tables 2 and 3), indicating their potential use for the introduction of heat tolerance for flowering to new cultivars.

Positive linear correlations existed between leaf electrolyte leakage and the degree of heat-induced flowering delay in chrysanthemum (Fig. 3). This is consistent with thermotolerance being correlated between the seedling and flowering stages among spring wheat cultivars (Fokar et al., 1998), winter wheat genotypes 
(Saadalla et al., 1990), and cowpea (Ismail and Hall, 1999). This technique is simple, quick, and less expensive than a whole plant screen. Potentially, breeders could use the technique with early vegetative-stage leaf tissue from plants grown in field.

If cellular processes could be identified that were involved both in CMT and in heat-induced delay in flowering of chrysanthemum then not only would the physiology of both be clearer but more ways to manipulate flowering might be suggested. Photosynthetic capacity is a likely candidate. Flowering is known to be delayed by environmental conditions that reduce assimilate supply (Dinar and Rudich, 1985; Kinet, 1993). More specifically, exposure of cells to heat disrupts the membrane lipid bilayer which can impact photosynthetic activity (Raison et al., 1980). It would be of interest to examine possible relationships between heat-induced changes in membrane structure, rate of flowering and carbon assimilation.

\section{Literature Cited}

Ahrens, M.J. and D.L. Ingram. 1988. Heat tolerance of citrus leaves. HortScience 23:747-748.

Anderson, N.O. and P.D. Ascher. 2001. Selection of day-neutral, heatdelay-insensitive Dendranthema $\times$ grandiflora genotypes. J.Amer. Soc. Hort. Sci. 126:710-721.

Anderson, J., G. McCollum, and W. Roberts. 1990. High temperature acclimation in pepper leaves. HortScience 25:1272-1274.

Cathey, H.M. 1954. Chrysanthemum temperature study. C. The effect of night, day, and mean temperature upon the flowering of chrysanthemums. Proc. Amer. Soc. Hort. Sci. 64:499-502.

Chauhan, Y.S. and T. Senboku. 1996. Thermostabilities of cell-membrane and photosynthesis in cabbage cultivars differing in heat tolerance. J. Plant Physiol 149:729-734.

Chen, H.H., Z.Y. Shen, and P.H. Li. 1982. Adaptability of crop plants to high temperature stress. Crop Sci. 22:719-725.

Cockshull, K.E. 1979. Effect of irradiance and temperature on flowering of Chrysanthemum morifolium Ramat. in continuous light. Ann. Bot. 44:451-460.

De Jong, J. 1989. The flowering of Chrysanthemum morifolium seedlings and cuttings in relation to seasonal fluctuation in light. Scientia Hort. 41:117-124.

Dinar, M. and J. Rudich. 1985. Effect of heat stress on assimilate partitioning in tomato. Ann. Bot. 56:239-248.

Fokar, M., H.T. Nguyen, and A. Blum. 1998. Heat tolerance in spring wheat. I. Estimating cellular thermotolerance and its heritability.
Euphytica 104:1-8.

Hall, A.E. 1992. Breeding for heat tolerance. Plant Breed. Rev. 10: 129-168.

Inaba, M. and P.G. Crandall. 1988. Electrolyte leakage as an indicator of high-temperature injury to harvested mature green tomatoes. J. Amer. Soc. Hort. Sci. 113:96-99.

Ingram, D.L. and D.W. Buchanan. 1984. Lethal high temperatures for roots of three citrus root-stocks. J. Amer. Soc. Hort. Sci. 109:189-193.

Ismail, A.M. and A.E. Hall. 1999. Reproductive-stage heat tolerance, leaf membrane thermostability and plant morphology in cowpea. Crop Sci. 39:1762-1768.

Karlsson, M.G., R.D. Heins, J.E. Erwin, and R.D. Berghage. 1989. Development rate during four phases of chrysanthemum growth as determined by preceding and prevailing temperatures. J. Amer. Soc. Hort. Sci. 114:234-240.

Kinet, J.M. 1993. Environmental, chemical and genetic control of flowering. Hort. Rev. 15:279-334.

Lester, G.E. 1985. Leaf cell membrane thermostabilities of Cucumis melo. J. Amer. Soc. Hort. Sci. 110:506-509.

Martineau, J.R., J.E. Specht, J.H. Williams, and C.Y. Sullivan. 1979. Temperature tolerance in soybeans I. Evaluation of a technique for assessing cellular membrane thermostability. Crop Sci. 19:75-78.

Raison, J.K., J.A. Berry, P.A. Armond, and C.S. Pike. 1980. Membrane properties in relation to the adaptation of plants to temperature stress, $p$. 261-273. In: N.C. Turner and P.J. Kramer (eds.). Adaptation of plants to water and high temperature stress. Wiley, New York.

Saadalla, M.M., J.S. Quick, and J.F. Shanahan. 1990. Heat tolerance in winter wheat: II. Membrane thermostability and field performance. Crop Sci. 30:1248-1251.

Shibata, M. and J. Kawata. 1987. The introduction of heat tolerance for flowering from Japanese summer-flowering chrysanthemums into year-round chrysanthemums. Acta Hort. 197:77-81.

Sullivan, C.Y. 1972. Mechanisms of heat and drought resistance in grain sorghum and methods of measurement, p. 247-264. In: N.G.P. Rao and L.R. House (eds.). Sorghum in the seventies. Oxford \& IBH Publishing Co., New Delhi.

Sullivan, C.Y. and W.M. Ross. 1979. Selecting for drought and heat resistance in grain sorghum, p. 263-281. In: H. Mussell and R.C. Staples (eds.). Stress physiology in crop plants. Wiley, New York.

Whealy, C.A., T.A. Nell., and J.E. Barrett. 1987. High temperature effects on growth and floral development of chrysanthemum. J. Amer. Soc. Hort. Sci. 112:464-468.

Wu, M.T. and S.J. Wallner. 1993. Heat stress responses in cultured plant cells: Development and comparison of viability tests. Plant Physiol. $72: 817-820$ 